\title{
UJI ORGANOLEPTIS, pH, UJI EBER DAN CEMARAN BAKTERI PADA KARKAS YANG DIISOLASI DARI KIOS DI BANYUWANGI
}

\section{Organoleptic Test, pH Test, Eber Test and Bacterial Contaminant on Carcass that Isolated from Banyuwangi Market}

\author{
Faisal Fikri ${ }^{1 *}$, Iwan Sahrial Hamid ${ }^{1}$, Muhammad Thohawi Elziyad Purnama² \\ ${ }^{1}$ Departemen Ilmu Kedokteran Dasar, \\ ${ }^{2}$ Departemen Anatomi Veteriner, \\ Fakultas Kedokteran Hewan, Universitas Airlangga, \\ Kampus C Mulyorejo, Surabaya, Jawa Timur, Indonesia, 60115 \\ Telp.(031) 5993016, Fax.(031) 5990315 \\ *Corresponding author: faisalfikriunair@gmail.com
}

\begin{abstract}
Abstrak
Food borne disease merupakan isu bagi dunia kesehatan karena masih belum bisa dikendalikan secara tuntas. Daging merupakan salah satu agen tempat berkembangnya mikroba infeksius, cemaran kimia dan fisik yang memungkinkan timbulnya food poisoning. Penanganan masalah food borne disease melalui penatalaksanaan penyediaan pemotongan melalui Rumah Potong Hewan (RPH) menjadi salah satu kunci untuk mengendalikan bahan pangan. Kualitas daging menjadi prioritas penting dalam menjamin mutu pangan. Penelitian menggunakan kajian cross sectional study dengan metode sampling purposive. Pengujian sampel di wilayah Kecamatan Banyuwangi, Genteng dan Kalibaru menjadi subjek utama dimana terdapat kios daging yang mensuplai kebutuhan konsumen sehingga akan diketahui kualitas daging yang dipotong melalui RPH. Penelitian ini menunjukkan hasil uji organoleptis warna 37\% kelainan, bau normal, tekstur konsistensi keras 0,05\%, uji pH 50\% diatas ambang normal, uji Eber $45 \%$ positif mengalami awal kebusukan. Semua sampel daging negative Salmonella spp dan 50\% melebihi ambang batas Standart Nasional Indonesia cemaran Escherichia coli.
\end{abstract}

Kata kunci: karkas, organoleptis, Salmonella spp, Escherichia coli, Banyuwangi

\section{Abstract}

Food borne disease is an important health issue. Carcass can contamine with microbial hazard, infectiuous agent, chemistry hazard and physic hazard that cause food poisoning. Handling of food borne disease by good management on animal slaughter become an important thing to control food hygiene. Carcass quality become a priority to guarantee food safety. Animal slaughter produce high quality of carcass on all aspects ie: safety, healthy, complete and halal. This study was used cross sectional studies and purposive sampling to collect carcass. Samples were collect from traditional market in district of Banyuwangi, Genteng and Kalibaru. Traditional market supply primary carcass from animal slaughter. This study showed that organoleptic test ie: abnormall colour 37\%, normal flavor, hard consistency 0,05\%, pH test upper normal 50\%, Eber test $45 \%$ positive. All of samples were showed negative of Salmonella spp and more than 50\% SNI threshold positive of Escherichia coli.

Key words: carcass, organoleptic, Salmonella spp, Escherichia coli, Banyuwangi

\section{PENDAHULUAN}

Food borne disease adalah penyakit yang disebabkan konsumsi makanan atau minuman yang tercemar mikroorganisme patogen, zat-zat toksik, dan bahan non nutrisi baik berasal dari hewan maupun tumbuhan. Food borne disease dapat melalui agen yang bersifat toksik maupun infeksius yang terapapar ke dalam makanan. Istilah lain yang digunakan adalah keracunan makanan (food poisoning) yang penyebab infeksinya berupa biologis, fisik, maupun kimiawi yang mengakibatkan manifestasi pada gangguan pencernaan dan gejala yang sistemik (Jay, 2005). 
Penjaminan terhadap kualitas daging menjadi salah satu upaya untuk menjaga rasa aman dan nyaman dalam konsumsi bahan produk asal hewan agar mencakup standart keamanan pangan (food safety) (Cheng dan Sun, 2008). Kualitas karkas merupakan nilai karkas yang dihasilkan oleh ternak relatif terhadap suatu kondisi pemasaran. Jumlah daging dan kualitas daging menjadi faktor penting yang menentukan nilai karkas. Nilai karkas dapat ditinjau dari tipe ternak asal karkas, lemak intramuskular atau marbling di dalam sturktur otot. Faktor nilai karkas dapat diukur secara objektif, misal berat karkas, sedangkan secara subjektif dapat diukur dengan pengujian organoleptik atau panel method (Cheng dan Sun, 2008).

Faktor kualitas daging meliputi warna, keempukan dan tekstur, aroma, citarasa dan jus daging (juiciness). Selain itu, lemak intramuskular dan susut mamasak (cooking loss) yaitu berat sampel daging yang hilang selama pemasakan atau pemanasan, retensi cairan dan $\mathrm{pH}$ daging ikut menentukan kualitas daging (Anil et al., 2002). Faktor sebelum dan sesudah pemotongan dapat mempengaruhi kualitas karkas. Faktor sebelum pemotongan yang dapat mempengaruhi kualitas daging antara lain: genetik, spesies, bangsa, tipe ternak, jenis kelamin, umur, pakan, termasuk bahan aditif (hormon, antibiotik, dan mineral) dan stres. Faktor setelah pemotongan mempengaruhi kualitas daging antara lain meliputi metode pelayuan, stimulasi listrik, metode pemasakan, pH karkas dan daging, bahan tambahan termasuk enzim pengempuk daging, hormon dan antibiotik, lemak intramuskular atau marbling, metode penyimpanan dan preservasi, macam otot daging dan lokasi otot daging (Cheng dan Sun, 2008).

Menurut Permentan nomor 13 Tahun 2010 yang menyatakan bahwa Rumah Potong Hewan (RPH) merupakan sebuah kompleks bangunan yang didesain untuk melaksanakan tugas pokok dan fungsi utama untuk memotong hewan ternak potong dengan standart aman, higienis, sanitasi, dan halal. Fungsi RPH dapat menjadi sarana kontrol untuk mendapatkan kualitas daging atau karkas yang Aman, Sehat, Utuh dan Halal
(ASUH). Rumah Potong Hewan dapat menjamin keterlaksanaan pasokan konsumsi daging melalui proses yang telah distandardisasi sehingga menjadi harapan untuk mencegah persebaran food borne disease yang masif. Berdasarkan latar belakang tersebut perlu dilakukan penelitian tentang bagaimana kualitas karkas yang diisolasi dari kios daging di Kabupaten Banyuwangi.

\section{METODE PENELITIAN}

Penelitian bersifat kuantitatif yang menggunakan kombinasi kajian epidemiologi dengan pendekatan cross sectional study. Penentuan tempat berdasarkan pada kriteria khusus sampling purposive pada penelitian yang dapat merepresentasi sampel yang dibutuhkan sebagai data penelitian.

Sampel penelitian diambil dari Kecamatan Banyuwangi, Kecamatan Genteng dan Kecamatan Kalibaru. Sampel didapatkan dari sentra pasar rakyat yakni kios penjualan daging hewan yang berasal dari pemotongan di Rumah Potong Hewan (RPH). Subjek yang akan diteliti adalah setiap kios pada pasar di kecamatan yang telah ditentukan sebagai tempat pengambilan sampel.

Instrumen penelitian yang digunakan adalah sampel atau spesimen daging yang diperoleh dari setiap kios kemudian diuji secara organoleptik, $\mathrm{pH}$, dan jumlah cemaran mikroorganisme akan diisolasi dengan media kultur dan diidentifikasi dengan uji biokimia untuk menentukan kadar dan potensi food borne disease. Nilai $\mathrm{pH}$ diukur dengan menggunakan pengukuran $\mathrm{pH}$ meter.

Analisis Data yang didapat akan diakumulasi dan dideskripsikan dengan membaca hasil pengamatan organoleptic, $\mathrm{pH}$ dan jumlah cemaran mikroorganisme sesuai SNI.

\section{HASIL DAN PEMBAHASAN}

Hasil uji kualitas karkas meliputi pemeriksaan organoleptis, kadar $\mathrm{pH}$ dan uji awal kebusukan dapat dilihat pada tabel 1 yang merupakan keseluruhan sampel yang diambil dari pasar di Kecamatan Banyuwangi, 
Kecamatan Genteng dan Kecamatan Kalibaru. Selanjutnya sampel diuji secara mikrobiologi untuk mengetahui cemaran bakteri Salmonella spp dan Escherichia coli yang terdapat pada sampel daging yang telah diambil sebagai sampel penelitian dapat dilihat pada tabel 2 .

Tabel 1. Hasil uji kualitas daging di Kecamatan Banyuwangi, Genteng dan Kalibaru

\begin{tabular}{|c|c|c|c|c|c|c|}
\hline \multirow{2}{*}{ No } & \multirow{2}{*}{ Kode Sampel } & \multicolumn{3}{|c|}{ Uji Organoleptis } & \multirow{2}{*}{ Uji pH } & \multirow{2}{*}{ Uji Eber } \\
\hline & & Warna & Bau & Tekstur & & \\
\hline 1 & B0615181116 & merah khas daging & khas daging & kenyal & 5 & + \\
\hline 2 & B0611181116 & merah khas daging & khas daging & kenyal & 6 & - \\
\hline 3 & B0620181116 & merah tua & khas daging & keras & 6 & + \\
\hline 4 & B0616181116 & merah khas daging & khas daging & kenyal & 5,5 & - \\
\hline 5 & B0613181116 & merah khas daging & khas daging & kenyal & 6 & - \\
\hline 6 & B0621181116 & merah khas daging & khas daging & kenyal & 5 & - \\
\hline 7 & BM0641181116 & merah khas daging & khas daging & kenyal & 5 & + \\
\hline 8 & BM0635181116 & merah khas daging & khas daging & kenyal & 5 & + \\
\hline 9 & BM0607181116 & merah khas daging & khas daging & kenyal & 5 & - \\
\hline 10 & BM0629181116 & merah khas daging & khas daging & kenyal & 5 & - \\
\hline 11 & G0630181116 & merah khas daging & khas daging & kenyal & 6 & - \\
\hline 12 & G0630181116 & merah khas daging & khas daging & kenyal & 6 & - \\
\hline 13 & G0630181116 & merah khas daging & khas daging & kenyal & 5 & - \\
\hline 14 & G0630181116 & merah khas daging & khas daging & kenyal & 6 & - \\
\hline 15 & G0643181116 & merah khas daging & khas daging & kenyal & 5,5 & - \\
\hline 16 & K0629181116a & merah tua & khas daging & kenyal & 5,5 & - \\
\hline 17 & K0630181116 & merah tua & khas daging & kenyal & 5 & - \\
\hline 18 & K0629181116b & pucat & khas daging & kenyal & 5 & + \\
\hline 19 & K0628181116 & merah tua & khas daging & kenyal & 5,5 & + \\
\hline 20 & K0635181116 & merah tua & khas daging & kenyal & 6 & + \\
\hline 21 & K0610181116 & merah khas daging & khas daging & kenyal & 5 & + \\
\hline 22 & K0631181116 & merah tua & khas daging & kenyal & 5 & + \\
\hline
\end{tabular}

Keterangan standart normal: warna merah; bau khas daging; tekstur kenyal; $\mathrm{pH}$ 5,3 - 5,9; uji Eber (-)

Tabel 2. Hasil Uji mikrobiologi daging di Kecamatan Banyuwangi, Genteng dan Kalibaru

\begin{tabular}{lccccccc}
\hline \multicolumn{2}{c}{ Parameter Uji } & \multicolumn{7}{c}{ Hasil Uji } \\
& & B1 & B2 & B3 & B4 & B5 & B6 \\
\hline \multirow{2}{*}{ Mikrobiologi } & Escherichia coli & 3,6 & 3,6 & $<3$ & $<3$ & $<3$ & 3,6 \\
& Salmonella spp & - & - & - & - & - & - \\
\hline
\end{tabular}

Keterangan: Escherichia coli $<3$ APM/g; Salmonella spp negative (-)

Berdasarkan hasil organoleptis untuk warna $37 \%$ kelainan, bau normal sedangkan pada tekstur satu sampel yang abnormal yaitu dengan konsistensi keras 0,05\%, uji pH 50\% diatas ambang normal, pada uji eber didapatkan $45 \%$ positif mengalami awal kebusukan. Menurut Soeparno (2005) standart $\mathrm{pH}$ daging ideal berkisar antara 5,3-5,9. Kadar $\mathrm{pH}$ standart juga sangat tergantung pada laju glikolisis post mortem dan cadangan glikogen dalam otot. Semakin rendah kadar glikogen daging, maka semakin lambat proses glikolisis dan $\mathrm{pH}$ ultimate semakin tinggi. Glikogen dalam otot juga dapat dipengaruhi kondisi ternak sebelum dan sesaat sebelum dipotong seperti stress yang dialami ternak. Selain itu, injeksi hormone, obat-obatan, spesies, individu ternak, jenis otot, stimulasi listrik, aktivitas enzim dapat mempengaruhi 
proses glikolisis. Suhu rendah dapat menghambat laju penurunan $\mathrm{pH}$, dan sebaliknya suhu tinggi dapat mempercepat laju penurunan $\mathrm{pH}$.

Aberle et al. (2001) menyebutkan bahwa kadar $\mathrm{pH}$ dapat berubah setelah ternak dipotong. Kondisi fisiologis otot yang berhubungan dengan produksi asam laktat atau kapasitas produksi energi otot dalam bentuk ATP dapat mempengaruhi penurunan nilai $\mathrm{pH}$. Warna, bau dan tekstur semua sampel daging menunjukkan hasil yang memenuhi standart. Indicator kualitas daging berdasarkan warna daging yakni merah hingga merah tua, bau khas daging, dan tekstur empuk. Lawrie (2003) dan Soeparno (2005) menyebutkan bahwa warna daging dipengaruhi oleh beberapa factor yaitu pakan, spesies, bangsa, umur, jenis kelamin, stress (tingkat aktivitas dan tipe otot), $\mathrm{pH}$ dan oksigen.

Soeparno (2005) menyebutkan bahwa myoglobin dapat berubah menjadi gelap yang disebabkan oleh $\mathrm{pH}$ post-mortem dan daya ikat air yang tinggi serta memiliki tekstur yang lekat. Warna gelap pada daging berhubungan tidak langsung dengan $\mathrm{pH}$ namun erat kaitannya dengan aktivitas mitokondria sehingga konsentrasi oksimyoglobin merah terang tetap rendah. Mioglobin sebagai salah satu dari protein sarkoplasmik terbentuk dari suatu rantai polipeptida tunggal terikat di sekeliling groupheme yang membawa oksigen. Group heme tersusun dari suatu atom $\mathrm{Fe}$ dan suatu cincin porfirin. Perbedaan warna daging antar spesies disebabkan konsentrasi mioglobin, yang akan meningkat seiring dengan meningkatnya umur ternak (Soeparno, 2005).

Warna daging yang disukai konsumen adalah merah cerah yang menunjukkan mutu daging. Perubahan warna daging dipengaruhi oleh banyak faktor. Daging yang terekspos dengan udara $(\mathrm{O} 2)$, mioglobin dan oksigen dalam daging akan bereaksi membentuk ferrousoxymioglobin (OxyMb) sehingga daging akan berwarna merah cerah. Apabila waktu kontak antara mioglobin dengan oksigen berlangsung lama, maka akan terjadi oksidasi membentuk ferricmetmyoglobin (MetMb), sehingga daging berwarna coklat dan tidak menarik (Aberle et al., 2001; Jeong et al., 2009).

Pengujian mikrobiologi dilakukan untuk mengetahui cemaran mikroba yang terdapat dalam sampel daging. Berdasarkan penelitian bahwa sampel daging B1, B2, B6 tidak memenuhi standart cemaran E. coli yakni $>3$ APM/g. Sedangkan Salmonella spp memenuhi standart yakni negative.

E. coli merupakan mikroba normal di saluran pencernaan dan bersifat patogen, namun dengan proses pemasakan yang sempurna $E$. coli dapat musnah karena mikroba ini bersifat sensitif terhadap panas pada suhu $60^{\circ} \mathrm{C}$ selama 30 menit. E. coli merupakan bakteri gram negatif yang hidup pada usus besar manusia hal ini yang disebut sebagai flora normal, namun jika bakteri ini memasuki saluran pencernaan dari bahan makanan seperti bahan asal hewan dan produk olahannya dapat menyebabkan diare yang akut (gastroenteritis) sehingga sangat perlu diwaspadai (Endang, 2009).

Kontaminasi dari bakteri E.coli pada daging sapi terkait erat dengan masih rendahnya masalah sanitasi dalam proses penanganan daging. Proses penyiapan daging di pasar Tradisional kurang memperhatikan aspek sanitasi dan higiene, karena daging-daging yang dipersiapkan untuk dijual oleh pedagang tidak ditutup dan disimpan dalam suhu dingin dan akibat dari suhu penyimpanan ini akan berdampak pada perkembangbiakan bakteri secara cepat, selain itu daging yang dibawa dari RPH hanya menggunakan gerobak tanpa alas yang artinya daging tersebut dibiarkan terbuka pada saat pengangkutan. Soeparno (2005) menyatakan bahwa selain faktor nutrisi, pertumbuhan mikroorganisme dalam daging juga dipengaruhi oleh faktor lingkungan khususnya temperatur.

\section{KESIMPULAN}

Hasil organoleptis warna 37\% kelainan, bau normal, tekstur konsistensi keras $0,05 \%$, uji $\mathrm{pH}$ $50 \%$ diatas ambang normal, uji Eber $45 \%$ positif mengalami awal kebusukan. Uji mikrobiologis seluruh sampel negatif Salmonella spp tetapi 
50\% melebihi ambang batas Standart Nasional

Indonesia cemaran Escherichia coli.

\section{UCAPAN TERIMA KASIH}

Peneliti mengucapkan terima kasih kepada RKAT PSDKU Universitas Airlangga Banyuwangi atas dana hibah penelitian, Dinas Pertanian Kabupaten Banyuwangi dan Lembaga Penelitian dan Inovasi Universitas Airlangga atas bimbingan luaran penelitian.

\section{DAFTAR PUSTAKA}

Aberle, E.D., J.C. Forrest, D.E. Gerrard, E.W. Mills. 2001. Principles of Meat Science. 4th edition. Kendal/Hunt Publishing Company.

Agbeniga, B., E.C. Webb. 2014. Influence of electrical stimulation on carcass and meat quality of Kosher and conventionally slaughtered cattle. J. Anim. Sci. 44:5(1).

Anil, M.H., S. Love, C.R. Helps, D.A. Habour. 2002. Potential for carcass contamination with brain tissue following stunning and slaughter in cattle and sheep. Food Control. 13, 431-436.

Cheng, Q.F., D.W. Sun. 2008. Factors affecting the water holding capacity of red meat products: A review of recent research advances. Crit. Rev. Food Sci. Nutr. 48, 137159.
Dinas Peternakan Provinsi Jawa Timur. 2015. Data Rumah Potong Hewan Se Jawa Timur. Surabaya. [Diakses 9 April 2015].

Endang, S. 2009. Tinjauan Bahan Pangan Asal Hewan Yang Asuh Berdasarkan Aspek Mikrobiologi di DKI Jakarta. Jakarta. http://peternakanlitbang.deptan.go.id.

Food Standards Australia New Zealand (FSANZ). 2013. Agents of foof borne illness. Ed $2^{\text {nd }}$. Australia-New Zealand.

Jay, J.M. 2005. Modern Food Microbiology. Gaithersburg, MD: Aspen Publishers.

Jeong, J. Y., S.J. Hur, H.S. Yang, S.H. Moon, Y.H. Hwang, G.B. Park, S.T. Joo. 2009. Discoloration characteristics of 3 major muscles from cattle during cold storage. Journal of food science, 74(1).

Lawrie, R.A. 2003. Ilmu Daging. Parakkasi A: penerjemah. UI Press. Jakarta. Terjemahan dari: Meat Science.

Permentan No.13 Tahun 2010. Tentang Rumah Potong Hewan.

Soeparno. 2005. Ilmu dan Teknologi Daging. Gadjah Mada University Press. Yogyakarta.

Syadiash. 2010. Pengertian dan Jenis-Jenis Pasar. Surakarta. 